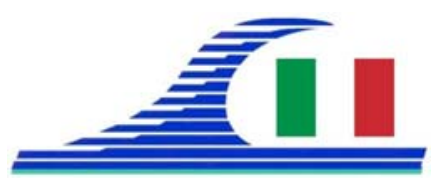

Conférence Méditerranéenne Côtière et Maritime EDITION 3, FERRARA, ITALIA (2015)

Coastal and Maritime Mediterranean Conference

Disponible en ligne - http://www.paralia.fr - Available online

\title{
Spatial and temporal evolution and morphodynamic zonation of the Ravenna shoreface
}

\author{
Flavia SISTILLI ${ }^{1}$, Frederico SCARELLI ${ }^{1,2}{ }^{1}$, Francesco STECCHI ${ }^{1}$, \\ Stefano FABBRI ${ }^{1}$, Luigi CANTELLI ${ }^{3}$, Giovanni GABBIANELLI ${ }^{1}$
}

1. University of Bologna, Department of Biological, Geological and Environmental Science, UOS Ravenna Campus, I-48123 Ravenna, Italy.

flavia.sistilli2@unibo.it

2. Universidade Federal do Rio Grande do Sul, Instituto de Geociências, Av. Bento Gonçalves 9500, 91509-900 Porto Alegre, RS, Brazil.

\begin{abstract}
:
The knowledge of the shoreface morphodynamic zonation is essential for coastal zone management, to support a large set of planning decisions and in the field of engineering. To have a real knowledge of the shoreface and its evolution, repeated bathymetric surveys on the same zone for several years should be done in order to quantify the sea bottom change.

To confront this problem, an assessment of principal limit depths was conducted, adopting well-known methods in literature on the basis of the local wave climate. The closure depth was estimated for typical and extreme values, based on the considered timescale.
\end{abstract}

Keywords: Shoreface zonation, Closure depth, Coastal management, Coastal environment, Extreme value analysis.

\section{Introduction}

On a wave-dominated coast, such as that of Ravenna, a basic driver of shoreface morphological change is the incoming waves and their capacity to move sea bottom sediment at different depths (wave base). Generally, in shallow water (upper shoreface) there is high movement of sediment and fast morphodynamic adaptation (bars and troughs) occurring over small time-scales (events, seasons, one year); in deeper water (middle-lower shoreface) only extreme storm waves are capable of moving sediments and the progressive evolution of cross-shore profile is slow (decades to century); beyond the deepest wave base there is a transition zone towards the inner shelf where morphological change occurs over geological time-scale (NICHOLLS et al., 1998; STIVE \& DE VRIEND, 1995). "Closure depth is a fundamental morphodynamic boundary separating a landward active zone from a seaward less active zone over the period defined" (NICHOLLS et al., 1996). This limit depth is the edge of the zone involved in a sediment exchange system that thus involves the submerged part of the coastal system. Closure depth is a statistical concept, because over a greater period of 
Côtes méditerranéennes menacées :

Risques et défis dans le contexte du changement climatique

observation there is greater possibility of having an event capable of moving sediment at larger depth (PRANZINI \& WETZEL, 2008).

The study area in Ravenna coast (Emilia-Romagna Region, Italy), is about $50 \mathrm{~km}$ of sandy and low gradient beaches located in the NW Adriatic Sea. Ravenna's coast is affected by many natural and anthropoghenic factors that increase the coastal vulnerability and at the moment it has segments with an erosive trend caused principally by anthropization (MARTINELLI et al., 2011). The Ravenna coastal plain presents a low elevation above mean sea level (MSL) (REGIONE EMILIA-ROMAGNA, 2010), the mean height is $1.45 \mathrm{~m}$ above MSL and the dune crests elevations are between 1.5 to $3 \mathrm{~m}$. The mean backshore/foreshore width is $70 \mathrm{~m}$ with mean slopes of $0.03(\tan \beta)$; the beaches may be classified as very dissipative beaches and the zone is characterized by a microtidal regime (ARMAROLI et al., 2012). According to ARMAROLI et al. (2012), storms are mainly generated by the "Bora" winds, which are strong winds from ENE; the "Scirocco" wind is another important wind from SE.

\section{Materials and method}

In order to identify the shoreface zonation for the Ravenna's coast, meteo-marine conditions are defined for the area and different values of closure depth were calculated according to the well-known relationship of HALLERMEIER (1978):

$D_{c}=2.28 H-68.5 H^{2} /\left(g T^{2}\right)$

where: $\mathrm{H}$ and $\mathrm{T}$ are respectively the local significant wave height and wave period and $g$ is the acceleration of gravity. Data used for the analysis cover a period from May 2007 to March 2015 and were obtained from Nausicaa, a wave buoy managed by EmiliaRomagna environmental regional agency (ARPA-ER), from Venezia buoy (national wave metric network) and from Angelina platform.

Following the method described in PRANZINI \& WETZEL (2008), typical and extreme values of closure depths are estimated. Typical closure depths are associated with small-medium temporal scale assessment. Extreme closure depths are associated with medium-large temporal scale assessment and were calculated on the basis of the value of significant wave height (Hs) and peak periods (Tp) for different return period (Tr) obtained by Extremes Value Analysis (EVA) carried out on the wave data. The EVA was conducted according to BRACA et al. (2013a), with the Anabasi Excel sheet (BRACA et al., 2013b), a series of "macro" implemented for helping the user in the analysis. For both parameters, the EVA was conducted on pre-selected events of storms identified according to MICORE criteria (ARPA-ER, 2011). The Peak Over Threshold (POT) series of data was therefore analyzed with a Generalized Pareto Distribution (GPD). Extreme values for $\mathrm{Hs}$, Tp and the respective extreme Dc were calculated for 5 , 10, 20, 50, 100 years of Tr. 
Mediterranean coasts at threat:

Hazards and challenges in the context of climate variability

\section{Results}

In order to calculate the typical Dc values, a complete distribution of Dc was calculated considering each value of the wave dataset. Starting from Dc data series, the values of interest were calculated: $\mathrm{DC}_{\text {MEAN }}$ is the average value of the series; $\mathrm{DC}_{95 \%}$ is the value at $95 \%$ in a cumulative frequency distribution; $\mathrm{DC}_{\mathrm{MAx}}$ is the maximum value of the series in association with the maximal $\mathrm{Hs}(3.9 \mathrm{~m})$ registered in the investigated period; $\mathrm{DC}_{\mathrm{H}}$ is the value in association with Hs that exceeded 12 hours per year, according to HALLERMEIER (1978).

To calculate the extreme Dc value, EVA is necessary to obtain the value of Hs and T for different Tr. This analysis was carried out with the Anabasi Excel sheet (BRACA et al., 2013b). On the basis of extreme values, extreme Dc values were calculated.

Table 1. Typical and Extreme closure depth (Dc) values.

\begin{tabular}{|c|c|c|c|c|}
\hline & $\mathrm{Dc}[\mathrm{m}]$ & $\mathrm{Hs}[\mathrm{m}]$ & $\operatorname{Dir}_{\mathrm{ME}, \mathrm{HN}}\left[{ }^{\circ} \mathrm{N}\right]$ & $\mathrm{Tp}[\mathrm{s}]$ \\
\hline$D_{c_{M E, H N}}$ & -0.9 & 0.4 & 101.9 & 4.3 \\
\hline Dc95\% & -2.7 & 1.3 & 64.4 & 6.6 \\
\hline Dc $c_{\text {MuX }}$ & -7.6 & 3.9 & 59.1 & 9.1 \\
\hline $\mathrm{D} \mathrm{c}_{\mathrm{H}}$ & -4.4 & 2.2 & 55.2 & 7.2 \\
\hline
\end{tabular}

\begin{tabular}{|l|c|c|c|}
\hline & $\mathrm{Dc}[\mathrm{m}]$ & $\mathrm{Hs}[\mathrm{m}]$ & $\mathrm{Tp}[\mathrm{s}]$ \\
\hline $\mathrm{D} c_{5 \mathrm{y}}$ & -8.2 & 4.1 & 10.2 \\
\hline $\mathrm{D} c_{10 \mathrm{y}}$ & -8.7 & 4.3 & 10.6 \\
\hline $\mathrm{D} c_{20 \mathrm{y}}$ & -9.1 & 4.5 & 10.9 \\
\hline $\mathrm{D} c_{50 \mathrm{y}}$ & -9.7 & 4.8 & 11.3 \\
\hline $\mathrm{D} c_{100 \mathrm{y}}$ & -10.0 & 5.0 & 11.6 \\
\hline
\end{tabular}

\section{Conclusions}

Shoreface morphodynamic zonation and evolution are important factors that need to be considered in integrated coastal zone management and monitoring applications, especially because it is in the submerged beach that coastal erosion starts. In this work was applied a practical method to estimate the principal limit depths between upper shoreface, lower shoreface and transition zone towards the inner shelf. The upper shoreface is the "active zone" and its depth limit, over a period of 8 years of available data, is about $\mathrm{DC}_{\mathrm{H}}-4 \mathrm{~m}$; this depth is determinated by a wave of $2.2 \mathrm{~m}$. The lower shoreface is the zone where a cross-shore sediment movement occurs during storms; obviously this limit is closely linked to a singular event; in this analysis the $\mathrm{DC}_{\text {MAx }}$ is about $-8 \mathrm{~m}$ associated with the highest Hs of the dataset, that is $3.9 \mathrm{~m}$.

The extreme Dc at 50 years return period, which is about $-10 \mathrm{~m}$, could be considered the effective one from an engineering point of view.

\section{Acknowledgements}

We acknowledge ISPRA, the environmental protection national agency, for the concession of Venezia's buoy wave data, and Dr. Giovanni Braca (ISPRA), the corresponding author of Anabasi Excel sheet, for the support in the wave data extreme value analysis. We are also grateful to ENI for providing the Angelina wave data. 
Côtes méditerranéennes menacées :

Risques et défis dans le contexte du changement climatique

\section{References}

ARMAROLI C., CIAVOLA P., PERINI L., CALABRESE L., LORITO S., VALENTINI A., MASINA M., (2012). Critical storm thresholds for significant morphological changes and damage along the Emilia-Romagna coastline, Italy. Geomorphology, Vol. 143-144, pp 34-51. http://dx.doi.org/10.1016/j.geomorph.2011.09.006

ARPA-ER -Emilia-Romagna- (2011). Le mareggiate e gli impatti sulla costa in EmiliaRomagna, 1946-2010.

BRACA G., BUSSETTINI M., LASTORIA B., MARIANI S. (2013a), Linee Guida per l'analisi statistica di base delle serie storiche di dati idrologici, ISPRA, Manuali e Linee Guida n. 84/13, Roma. http://www.isprambiente.gov.it/files/pubblicazioni/manualilineeguida/MLG_84_2013.pdf

BRACA G., BUSSETTINI M., LASTORIA B., MARIANI S. (2013b), ANABASI ANAlisi statistica di BAse delle Serie storiche di dati Idrologici - Macro a supporto delle Linee Guida ISPRA - Manuale d'uso, Allegato a "Linee Guida per l'analisi statistica di base delle serie storiche di dati idrologici", ISPRA, Manuali e Linee Guida n. 84/13, Roma

HALLERMEIER R.J. (1978). Uses for a calculated limit depth to beach erosion. Proceedings 16th Coastal Engineering Conference, pp 1493-1512.

MARTINELLI L., ZANUTTIGH B., DE NIGRIS N., PRETI M., (2011). Sand bag barriers for coastal protection along the Emilia Romagna littoral, Northern Adriatic Sea, Italy. Geotextiles and Geomembranes, Vol 29, pp 370-380. http://dx.doi.org/10.1016/j.geotexmem.2010.11.010

NICHOLLS R.J., BIRKEMEIER W.A., HALLERMEIER R.J. (1996). Application of the depth of closure concept. Proc. 25th ICCE. Orlando, FL, ASCE, New York, pp 3874-3887.

NICHOLLS R.J., LARSON M., CAPOBIANCO M., BIRKEMEIER W.A. (1998). Depth of Closure: Improving Understanding and Prediction, Proceedings of 26th International Conference on Coastal Engineering, pp 2888-2901.

PRANZINI E., WETZEL L. (2008). Beach erosion monitoring. Result from BEACHMED-e/OPTIMAL project.

REGIONE EMILIA-ROMAGNA (2010). Per la sicurezza del territorio 2007/2009. $41 \mathrm{p}$.

STIVE MJ.F., DE VRIEND H.J. (1995). Modelling shoreface profile evolution. Marine Geology, Vol. 126, pp 235-248. http://dx.doi.org/10.1016/0025-3227(95)00080-I 